\title{
The Adjudication of Traffic Accident That Causing the Victims Die from Adat Law Perspective in Sanggau Regency, West Kalimantan
}

\author{
Marina Rona ${ }^{1} \quad$ Rachmad Safa' ${ }^{2}{ }^{2} \quad$ Abdul Madjid $^{2} \quad$ Moh. Fadli $^{2}$ \\ 1. Ph.D Candidate at Faculty of Law, Brawijaya University, Indonesia \\ 2. Lecturer at Faculty of Law, Brawijaya University, Indonesia
}

\begin{abstract}
This study aims to determine the adjudication of traffic accident cases that causing death from adat law perspective in Sanggau Regency, West Kalimantan. The facts in the community adat law show that adat law is the choice to adjudge the case of a traffic accident that causing death which is called adat pati nyawa. This shows the existence of adat law in Sanggau Regency, West Kalimantan. The research is an empirical legal research, in which the author examines the substance of adat law to the adjudication of traffic accident cases that causing a death, collects the legal data through observations, interviews, and focus group discussions. The approach used is socio-legal-antro which examines the community law behavior, especially the practice of adat pati nyawa in Sanggau Regency, West Kalimantan. The findings obtained Indonesia as a country that has a diversity of ethnicities, cultures, customs and adat laws, hence the unification of law is not absolute and has to accommodate the law that is locally able to provide justice for the community. The essence of the adjudication adat law on traffic cases that causing death is an institution that is believed to have justification for providing the justice of the indigenous peoples of Dayak Hibun, in terms of historical and socio-anthropological values.
\end{abstract}

Keywords: Case Adjudication, Adat Law, Adat Pati Nyawa.

DOI: $10.7176 / \mathrm{JLPG} / 93-09$

Publication date: January $31^{\text {st }} 2020$

\section{A. Introduction}

Etymologically, ubi societas ibi ius means "Where there is society, there is a law". This jargon is often attached to the Roman legal figure Marcus Tullius Cicero (lived around 106-34 BC). Indeed, the meaning is outmoded but in reality, it is still valid and has been practiced. This shows the truth applies throughout the ages, where the law only grows and develops in a society, in a life struggle between humans and humans. ${ }^{1}$

The phrase used to start the access in answering the reason of the existence of law. Traditionally, society meant as a group of people who live together in a long time and resulted in a culture. The culture means the values of attitude and behavior in interacting in that society, and it makes a conflict interest. Therefore, the law dedicated to the norms that guarantee the recovery of this conflict hence create peace. In fact, the existence of adat law which is a set of unwritten norms and rules, which lives and applies to regulate the lives of adat law communities has created order and peace, even without state apparatus such as police, prosecutors and judges.

Indonesia with the concept of "Bhineka Tunggal Ika" or unity in diversity known for its diversity of cultures, religions, ethnicities, races, and classes. De Facto, the diversity shows the diversity of Indonesia in "Negara Kesatuan Republik Indonesia" or in brief as the unity of Indonesia. The area of Indonesia spread out from Sabang to Maurake with many natural resources. ${ }^{2}$ Thus, in adat community ${ }^{3}$ of Dayak Hibun ${ }^{4}$ in Sanggau Regency, West Borneo. The law used known as adat law, if there is a violation by a person or group of the community would give adat punishment by pomuntuh adat or adat judges through deliberation mechanism to achieve an agreement or known as adat law. Adat punishment given to recovery the natural balance that interfered with the violation. Therefore, adat community knows a slogan "life is contained by adat, died is contained by land". This becomes the guidelines for adat community of Dayak Hibun.

Enforcing, the emergency decree No. 1 the year 1951 (Undang-Undang Darurat Nomor 1 Tahun 1951) about Temporary Action to Organize the Unity of Power and Civil Court Procedures, thus adat criminal law enactment limited in Indonesian Law. In fact, adat law still uses in adat law of dayaknese. Hence, this research investigates the essence of adat law to solve the traffic accident that causing the victim died which verdict by

1 I Gusti Ketut Sutha, Bunga Rampai Beberapa Aspek Hukum Adat, (Yogyakarta: Liberty, 1987), p.1.

2 I Nyoman Nurjaya, Reorientasi Paradigma Pembangunan Hukum Negara dalam Masyarakat Multikultul perspektif Antropologi Hukum, Speech of Inauguration of Professor in the Field of Legal Studies at the Faculty of Law, Universitas Brawijaya Malang, 2007, p.1.

${ }^{3}$ The researcher use the term "adat law community" which means a group of individuals who have lived for generations in certain geographical areas and are bound by cultural identity, strong relationships with land, territories and natural resources in their Customary Territories, and value systems that determine economic, political, social institutions and laws governed through adat institution that has the authority to regulate its citizens.

${ }^{4}$ The researcher use the term "Hibun" based on the interview with some respondents. In some books or documents known as Ribun (one of sub-tribes of Dayak in West Kalimantan) 
adat pati nyawa. ${ }^{1}$ Determining of adat pati nyawa by pomuntuh adat or adat judges through a deliberation mechanism to achieve an agreement or known as adat $l^{2} w^{2}$, without through the criminal law system in Indonesia.

\section{B. Research Method}

This research is empirical legal research to examine the legal system that lives and develops with the community, especially adat law. Empirical research is a study that sees the law as reality, including social reality, cultural reality, and others3. The function of empirical legal research is to examine what is the essence of adat law in resolving cases of traffic accidents that causing death on Dayak Hibun. This study also examines the behavior of Dayak Hibun, particularly in terms of choosing to settle traffic accident cases that causing casualties through Adat institutions so that Adat law of Dayak Hibun has its own meaning on the process of settling traffic cases known as adat court. Based on deliberation to reach consensus, adat institution imposes sanctions on driver/suspect, owner and/or public transportation companies and heirs of suspect's families by paying fines of Adat Pati Nyawa.

This study uses a socio-legal-antro approach4 which is to examine the community legal behavior, especially the application of adat pati nyawa on the case study of adat law of Dayak Hibun in Sanggau Regency, West Kalimantan. The thought that law cannot be separated from social life in the form of values and attitudes/behaviors carried out so that in the view of empirical law (empirische rechtwetenschap), the study of law does not only involve mere normative aspects, but the law can be assessed from its empirical aspects namely how the law actually in people's lives.

The socio-legal approach to examine the objectives of adat law is the welfare of community members. In contrast, to the legal goals established by the state, namely to guarantee legal certainty. In order to achieve prosperity, not only certainty but also prosperity and justice. Therefore, adat law research has a large moral responsibility5.

The law is inseparable from the values, attitudes, and behaviors carried out by the lawmaking community itself. Muhamad Munir reinforced this logic by saying: "that the study of law does not only concern the normative aspect but the law can be assessed from its empirical aspect of how the law is actually in people's lives6."

As empirical legal research with a socio-legal-antro approach, the data analysis techniques used in this study is qualitative research. The process of collecting data in this study is observation, interviews, Focus Group Discussion, and biographies. Primary data has been collected, analyzed through three activities, namely: data reduction, data presentation and drawing conclusions/verification 7.

\section{Result And Disscusion}

\section{C.1. The Essence of Adat Pati Nyawa}

In ancient times, adat pati nyawa is interpreted as the price of blood for each head that is beheaded that known as ngayau $^{8}$. Actually, ngayau can only be understood in the context of the religious life of the Dayaknese ${ }^{9}$. The skull was handed over to the family who lost in headhunting. Therefore, the price of blood must be paid to the heirs of the victim's family. Payment of the price of blood is known as adat pati nyawa. Traditional fines in ancient times were in the form of replacements of the organs and senses of someone who died as a result of being beheaded ${ }^{10}$. Since the implementation of a joint agreement between the Dayak tribes known as the Dayak Agreement of 1894 (Results of the Anoi Tumbang Peace Meeting) on the uniformity of Dayak Adat Laws, then ngayau was officially banned ${ }^{11}$. In addition, the spread of Catholic and Christian religious missions, education and inter-tribal life relationships are increasingly widespread and the increasing flow of communication and

\footnotetext{
${ }^{1}$ J.U Lontaan, Sejarah-Hukum Adat dan Adat Istiadat Kalimantan Barat, (Pontianak, Pemerintah Tingkat I kalbar, 1975), p. 330.

${ }^{2}$ H.Abdurrahman, in the collection of writings, Mengenal Sistem Peradilan Adat 25 Sub Suku Dayak di Kabupaten Sanggau, (Pontianak: Lembaga Bela Banua Talino, 2009), p.vii-ix.

${ }_{3}^{3}$ Achmad Ali and Wiwie Heryani, Menjelajahi Kajian Empiris terhadap Hukum, (Jakarta: Pranadamedia Group, 2012 ), p.2.

${ }^{4}$ Rachmad Safa'at, Rekonstruksi Politik Hukum Pangan, Dari Ketahanan Pangan Ke kedaulatan Pangan, (Malang: UB Press,2013), p. 51

${ }^{5}$ Dominikus Rato, Hukum Adat Kontemporer, (Surabaya: LaksBang Justitia, 2015), p. 178

${ }^{6}$ Muchamad Munir, Penggunaan Pengadilan Negeri Sebagai Lembaga Untuk Menyelesaikan Sengketa Dalam Masyarakat, (Surabaya: Unair, 1996), p.38.

${ }^{7}$ Mattew B. Miles dan A. Mitchael Huberman, Analisis data kualitatif: Buku Sumber tentang Metode-Metode Baru, (Jakarta: UI Press, 1992), p.22.

${ }^{8}$ Abu Ahmadi, Antropologi Budaya: mengenal kebudayaan dan suku-suku bangsa di Indonesia, (Surabaya, CV. Pelangi, 1986), p. 218.

${ }^{9}$ Valentinus, Kehormatan Menurut Dayak Mualang dalam Persepektif Kehormatan Katolik, (Malang: Tesis STFT Widya Sasana, 1997), p.31-36.

${ }^{10}$ M.C. Shadee (Bijdragen tot de taal, land en volkenkunde 1903-1914) translated by P. Yeri OFMCap, Adat Istiadat Orang Dayak Landak dan Tayan, (Yogyakarta: Pohon Cahaya, 2016), p.317.

${ }^{11}$ JJ Kusni, Dayak Membangun: Kasus Dayak Kalimantan Tengah, (Universitas Michigan, s.n., 1994), p. 32.
} 
information among Dayaknese communities is very influential in the disappearance of headhunting.

Whereas, adat pati nyawa is still maintained until now as payment for the price of blood and organ replacement for people who died as a result of human actions. Specifically, this study examines and analyzes the decision of Adat Pati Nyawa in cases of severe traffic accidents. The verdict of adat pati nyawa is if the victims who die are the Dayak Hibun peoples. Therefore, even though the suspect is outside parties and or is not the Dayak Adat law community, they still obey to adat court's decision ${ }^{1}$.

Adat criminal law is a law that lives and develops as long as there are people and their interactions, therefore it cannot be erased by law $^{2}$. Decision of adat pati nyawa to the driver or the suspect by paying Adat fines in the form of traditional objects such as tajau (ceramic jars about 1.3 meters of high) and a white sarong as a substitute for the body, lila (small gunnery) as a substitute for backbones, a mesh as a substitute for the abdominal organs, a wire as a substitute for the veins, gong as a substitute for the voice (vocal cords), a copper pot as a substitute for the head, spearfish as for the fingers and several other organs.

At the time of payment Adat Pati Nyawa fines, the heirs of the victim and family members, as well as representatives of the village residents and all pomuntuh adat must attend to witness the procession. Therefore, the suspect and / or their families must prepare food and beverage supplies during the adat process.

As the example, there were cases of heavy traffic accidents on July 11, 2017 at Jalan Raya Bodok-Sosok Parindu District, Sanggau Regency that is a collision between the police number KB 4010 DV motorbike driven by Hengky crashed with a KB 5612 DD motorbike which resulted in the rider Lohal, an inhabitant of Layau Hamlet, Palem Jaya Village, Parindu District, Sanggau Regency, died. Furthermore, on July 20, 2017, the incident occurred at Balai Berkuak, Ketapang Regency where the oil tanker of PT. Patra Niaga with the police number KB 9610 SH driven by Tawi crashed with a motorbike which caused the rider Endang, a resident of Seranggas Hamlet, Gunam Village, Parindu District, Sanggau Regency, died. Both of these cases were victims of the Dayak Hibun law community, therefore the family heirs demanded the settlement of the case based adat pati nyawa.

The payment of Adat Pati Nyawa with a series of sanctions in the form of adat sanctions, such as sanggah parang, adat dahaso buai giling, adat bepasoah, adat penosak, adat pati nyawa to substitute the organs and adat mahabo and besopak can be explained as follows:

1. Adat Sanggah Parang carry out as soon as possible after a traffic accident where there are victims who died. This adat aims to relieve the emotions of the victim's family.

2. Adat Dahaso Buai Miling aims to appeal to God for safety, health and avoid danger to the heirs of the victim's family or villagers.

3. Adat Bepasoah aims to the funeral procession are safely and smoothly.

4. Adat Penosak aims to impose the amount of the fine that will be imposed on the driver/suspect based on the investigation of adat criminal case by listening to the witness statement and the driver/suspect statement.

5. Adat Pati Nyawa aims to replace the organs of the body and soul or life of the victim with traditional objects therefore the family or heir does not feel lost.

6. Adat Mahabo and Besopak aim to separate the lives of the victims who died from the heirs of the family therefore they could do daily activities without being overshadowed by the spirits of the victims.

Dayak Hibun law community views that human beings and the universe are inseparable from one another, packaged in the construction of cosmological-minded thinking. Therefore, to achieve happiness and balance of nature, all behaviors must consider the unseen supernatural powers and adapt to the procedures as determined ${ }^{3}$. Any violation of adat law or adat criminal act will result in damage not only to the level of the body and lives of humans (victims) but also causes disturbances or shocks in the magical realm due to natural imbalances. This has consequences, the settlement of the case is not enough to only the settlement but must also include restoring the balance of nature with traditional rituals.

The second amendment to the 1945 Constitution of the Republic of Indonesia provides recognition and respect for indigenous and tribal peoples, as Article 18B paragraph (2) states that "the State recognizes and respects the units of adat law communities and their traditional rights as long as they are alive and in accordance with the development of society and the principles of Negara Kesatuan Republik Indonesia (the Republic of Indonesia), which is stipulated in law ". Furthermore, Article 28i paragraph (3) states that: "Cultural identity and traditional rights are respected in harmony with the times and civilizations". Therefore, the mandate contained in the constitution must be obeyed by the state administration.

Further regulation through Decision of the Constitutional Court Number 35 / PUU- / 2012 concerning

\footnotetext{
${ }^{1}$ H.Abdurrahman dalam kumpulan tulisan, Mengenal Sistem Peradilan Adat 25 Sub Suku Dayak di Kabupaten Sanggau, (Pontianak: Lembaga Bela Banua Talino, 2009), p. vii-ix

${ }^{2}$ Hilman Hadikusuma, Hukum Pidana Adat, (Bandung: Alumni, 1984), hlm.20.

${ }^{3}$ I Made Widnyana, Hukum Pidana Adat Dalam Pembaharuan Hukum Pidana, (Jakarta: Fikahati Aneska, 2013), p.110.
} 
testing of Article 1 number 6 of the Forestry Law ${ }^{1}$ which gives the definition of adat forest was originally state forest but within the territory of the adat law community. Then the Constitutional Court emphasized that adat forests are not state forests. Rights forests are divided into adat forest over adat rights and individual forests or legal entities. On that basis, it is no longer possible for private forests to be within the state forest area or vice versa. At the highest level, the entire status of the forest is controlled by the state ${ }^{2}$.

Recognition of indigenous and tribal peoples is further recognized in Article 5 of Law No. 48 of 2009 concerning Judicial Power which states that: "Constitutional Justices and Judges must explore, follow, and understand the legal values and a sense of justice that lives in the community". Therefore, when deciding on a traffic case, especially a serious traffic accident, adat pati nyawa can be used as a basis for the judge's consideration. Judges and other legal apparatuses such as the police, prosecutors, and advocates are assigned to apply general legal regulations to concrete events, making a process of concretization or individualization of legal rules that are general to concrete cases $^{3}$.

The enactment of Law Number 22 The year 2009 concerning Traffic and Road Transportation ${ }^{4}$ states that $^{2}$ "A traffic accident is a criminal offense", further on Article 229 paragraph (1) states that: "Traffic accidents are classified as aminor traffic accident, medium traffic accident and heavy traffic accident ". Article 229 clause (4) states that: "Serious traffic accidents as referred to in clause (1) may be caused by the negligence of road users, improper vehicles, as well as road and/or environmental inadequacies". Then reaffirmed in the provisions of Article 230 states that: "the case of traffic accidents as referred to in Article 229 paragraph (2), (3), and paragraph (4) are processed by criminal justice procedures in accordance with statutory provisions". Furthermore Article 235 paragraph (1) confirms that: "If the victim dies as a result of a serious traffic accident as referred to in Article 229 paragraph (1) letter c, the driver, owner, and/or Public Transport Company shall provide assistance to the heirs of the victim in the form of medical expenses and/or funeral costs by not invalidating criminal case demands". This contradicts the essence of Adat Pati Nyawa.

\section{C.2 Adat Court for Adat Law Community}

Adat law community in Indonesia, use terms that are very diverse to mention the mechanism of case resolving (disputes/violations) which is often called adat court. This term is often used on adat council meetings, adat meetings or specific expressions of each region. The community with the prevailing adat law mechanism views that any crime or violation is not seen as a crime or violation of the state, but rather a social problem of the community, which puts the settlement process involving the community itself, especially the parties (suspect and victim) as well as heirs/families with a deliberation mechanism for consensus and the resolving of the case through a adat court mechanism. Adat court can play a role by utilizing local wisdom as a conflict resolving through local and informal institutional mechanisms. Adat law community prefers this mechanism than the formal/state court mechanism.

Dayak Hibun law community uses the term "bokuduong adat". Bokuduong adat is a meeting to discuss various life problems of the Dayak Hibun people, both those relating to customs and adat violations. The matters relating to customs are usually related to custom equipment that is prepared when they want to perform a traditional ritual. For example, when they want to build a new house, then the person who is involved in advance prepares traditional equipment such as hancok that as one of the symbols in traditional rituals. In this case, it is not interpreted as a violation of adat, but rather on customs. But if there is a violation of adat, the process of settling the case is known as "bahada" or bucaho. In bucaho / bahada, the parties present and involved in the process are as follows:

1. Pomuntuh Adat, are traditional elders or known as adat judges institution consisting of Temonggong, Pateh / Mangku, Hiyo / Jago / Singo, Pasirah;

2. The parties to the litigation include heirs;

3. Let pucaho from both litigation parties, those are people who are experts in traditional law appointed by litigants;

4. Witnesses, usually appointed by litigants;

5. Village Officials, each representing representatives of the parties;

6. Adat Law Community as the witnesses the process of settling a case.

Regard to cases of traffic accidents causing in death, after bucaho / bahada process, is held, the number of sanctions or fines known as "tango" are decided by the adat judges according to their authority. Dayak Hibun

\footnotetext{
${ }^{1}$ Look at Republic of Indonesia State Gazette Year 1999 Number 167, Additional LNRI Number 3888. Researchers use the Forestry Law referred to as Law Number 41 Year 199 regarding Forestry.

${ }^{1}$ Noor Sidharta Effendi, Mahkamah Konstitusi Dan Perlindungan Hak Sosial Masyarakat Hukum Adat, a paper on Constitutional Law Festival di Universitas Brawijaya, 7 October 2016.

${ }^{3}$ Sudikno Mertokusumo, Penemuan Hukum sebuah pengantar, (Yogyakarta: Liberty, 2001), p. 37-38.

${ }^{4}$ Researchers use the term UULLAJ to mention Law Number 22 Year 2009 concerning Road Traffic and Transportation. Can be seen in LNRI Year 2009 Number 96. Additional State Gazette of the Republic of Indonesia Number 5025.
} 
adat community in Sanggau District, West Kalimantan, has chosen to use adat law as an institution to settle cases of traffic accidents causing death.

Adat court grows and develops naturally and genuine in togetherness with the birth of the unity of adat law community, which is the essence of adat court referred to in this paper. Therefore, adat court still exists as long as there is life from the adat law community itself. This is illustrated in the daily practice of the life of the Dayak adat community of West Kalimantan in general still resolving their disputes and/or cases through adat court.

Due regard to the above, the concept of adat court can be elaborated as follows:

1. Adat court is the justice system that lives in adat law community units in Indonesia;

2. Adat court based on adat law;

3. Adat court is not part of the state justice system;

4. Adat court has the authority to adjudicate adat cases, whether in the form of disputes or violations of adat law;

5. Adat court has the authority to adjudicate cases between members of adat law community and outside parties.

Dayak Hibun adat community chose to settle their case through adat court, on the basis of several reasons including:

1. Trustworthy, for the litigants, adat justice as a trusted institution. Because Pomuntuh Adat are people who have integrity and honesty and work unconditionally. Their daily lives also live with adat law community itself.

2. Deliberation of consensus, that in the trial process in adat court is open so that the litigants can be directly involved.

3. Openness, bucaho adat process especially related to traffic accident cases that causing death of victims is carried out openly and attended by various parties.

4. Fast, traffic accident case that causing death is carried out quickly, especially related to adat sanggah parang after the incident.

5. Genuine, pomuntuh adat who became judges during bucaho worked sincerely and full of responsibility.

6. Peace, bucaho adat process is carried out peacefully between the suspect / the charged with the victim.

7. Fair, carried out fairly where Pomuntuh Adat always consider every statement both from the suspect/the charged and the victim.

8. Joint Responsibility, the decision on sanctions/adat fines is a shared responsibility, both the heirs/victims' families and suspect.

9. Sustainability, adat court process needs to consider the sustainability of the lives of the parties.

The political reality of the law of unification of the state court has denied the existence of adat law and adat court. Hence, all disputes or case resolving puts forward state law and state court. Though adat law and adat court existed long before the Republic of Indonesia was proclaimed. Therefore, in the future adat court should have a place in the judicial authority in Indonesia which shows legal pluralism, including judicial bodies, hence, there is recognition of the existence of adat court as a judicial system outside the State court.

\section{C.3. Structure and System of Adat Court}

When people imagine adat court as imagined the structure and system of the state court system which has offices with complete facilities and with well-appointed judges, people will get lost and will not find adat court. Adat court is a justice system that was born, developed and practiced by adat law communities in Indonesia, based on adat law, where justice is not part of the state court system.

Along with the development of the times with a growing population, where the necessities of life and problems that arise in the community more and must be addressed, then they divide the tasks in authority over the implementation of community life. The division of tasks and authority forms a regular pattern and structure. They as a whole in Dayak Hibun legal community are called Pomuntuh Adat, which consists of:

1. Temonggong is the highest Pomuntuh Adat who has an indigenous territory consisting of several helmets and or villages;

2. Mangku/Pateh is Pomuntuh Adat who holds adat territory of several villages within adat territory of Temonggong, hence, his life of community functions as an assistant/representative of Temonggong;

3. Domuong is Pomuntuh Adat who holds only one adat village and is usually given the title: Hiyo/Nato/Hango/Jayo/Singo;

4. Kebayan/Pesirah is Pomuntuh Adat in one village as a servant / representative of Domuong;

5. Pongurus/Penoncoang is Pomuntuh Adat in one village as an assistant / representative of Kebayan/Pesirah.

They are people who understand and are capable and have integrity in solving adat law issues so that when juxtaposed with the state court, they are like adat judges. The process of settling a case or known as bucaho by 
using adat law is better known as adat court.

Pomuntuh Adat are chosen by adat law community itself, because personally, they are the chosen people, such as:

1. Understanding about customs and adat law and as a learner;

2. Having the soul of social leadership, because as Pomuntuh Adat, they did not get salary or honorarium;

3. Having good social relations, Pomuntuh Adat is expected to be a person who has a wide association;

4. Living in certain adat community, Pomuntuh Adat are chosen from local people who live in the community.

Thus, Dayak Hibun law community believes Pomuntuh Adat certainly will not hurt/harm its villagers, hence the causing decision must consider the humanitarian element.

\section{Conclusions}

The essence of adat court in the settlement of traffic cases that causing death is an institution perceived that having justification in providing justice. This is supported by the historical and socio-anthropological values of Dayak Hibun law community.

Historical value is a value embraced by a society based on the history of human civilization itself. Adat court as an institution perceived that having justification in providing justice in the settlement of a case in the Dayak Hibun law community. The practice of resolving a case through an adat institution is hereditary. Deciding on a case, they really absorb the aspirations of the community and do not give a heavy decision so that it surpasses human capability and preserves the humanity of the Dayak Hibun.

Socio-anthropological value is value embraced by the community, regarding what is considered good and what is considered bad by society. To determine whether something is said to be good or bad, appropriate or inappropriate must go through a process of weighing. Hence, it has a big influence on the dynamics of human life. This socio-anthropological value is abstract, but they are reflected in the behavior of individual or groups and the culture of a society that embraces these values. Adat judge who decides a case in the adat court is known as Pomuntuh adat. In Dayak Hibun law community, Pomuntuh adat consists of Temonggong, Pateh/Mangku, Hiyo/Jago/Singo, Pasirah. They have different authorities in deciding a case. Adat judges are chosen because they are considered capable of adat law and have integrity. They are born, grow and develop from the culture of the adat law community itself. Therefore, they really understand the values that live in the Dayak Hibun law community.

\section{References}

Abu Ahmadi. 1986. Antropologi Budaya: mengenal kebudayaan dan suku-suku bangsa di Indonesia, Surabaya, CV. Pelangi.

Achmad Ali dan Wiwie Heryani. 2012. Menjelajahi Kajian Empiris terhadap Hukum, Jakarta: Pranadamedia Group.

Dominikus Rato. 2015. Hukum Adat Kontemporer, Surabaya: LaksBang Justitia.

Hedar Laujeng. 2003. Mempertimbangkan Peradilan Adat: Seri Pengembangan Wacana, Jakarta: HuMa.

Herbert L. Paker, The Limit of The Criminal Sanction, California: Stanford University Press.

Howard Zehr, Chaging Lenses: A new Focus for Crime and Justice, Ontario: Herald Press.

H.Abdurrahman, the collection of writings. 2009. Mengenal Sistem Peradilan Adat 25 Sub Suku Dayak di Kabupaten Sanggau, (Pontianak: Lembaga Bela Banua Talino), hlm.vii-ix.

I Gusti Ketut Sutha. 1987. Bunga Rampai Beberapa Aspek Hukum Adat, Yogyakarta: Liberty.

I Made Widnyana. 2013. Hukum Pidana Adat Dalam Pembaharuan Hukum Pidana, Jakarta: Fikahati Aneska.

I Nyoman Nurjaya. 2007. Reorientasi Paradigma Pembangunan Hukum Negara dalam Masyarakat Multikultul perspektif Antropologi Hukum, Pidato Pengukuhan Guru Besar Dalam Bidang Ilmu Hukum Pada Fakultas Hukum Universitas Brawijaya Malang.

JJ Kusni. 1994. Dayak Membangun: Kasus Dayak Kalimantan Tengah, Universitas Michigan: s.n.

J.F. Holleman. 1981. Van Vollenhoven on Indonesian Adat Law: Selection from het Adatrecht van Nederlandsch-Indie.

J.U Lontaan.1975. Sejarah-Hukum Adat dan Adat Istiadat Kalimantan Barat, Pontianak: Pemerintah Tingkat I kalbar.

M.C. Shadee, dialihbahasakan oleh P. Yery OFM Cap.2016. Adat Istiadat Orang Dayak Landak dan Tayan, Yogyakarta: Pohon Cahaya.

Mattew B. Miles dan A. Mitchael Huberman. 1992. Analisis data kualitatif: Buku Sumber tentang MetodeMetode Baru, Jakarta: UI Press.

Muchamad Munir. 1996. Penggunaan Pengadilan Negeri Sebagai Lembaga Untuk Menyelesaikan Sengketa Dalam Masyarakat, Surabaya: Unair.

Rachmad Safa'at. 2013. Rekonstruksi Politik Hukum Pangan, Dari Ketahanan Pangan Ke kedaulatan 
Pangan, Malang: UB Press.

Sudikno Mertokusumo. 2001. Penemuan Hukum Suatu Pengantar, Yogyakarta: Liberty.

Noer Sidharta Effendi. 2016. Mahkamah Konstitusi dan Perlindungan Hak Sosial Masyarakat Hukum Adat, Makalah pada Constitutional Law Festival di Universitas Brawijaya, Malang.

Valentinus. 1997. Kehormatan Menurut Dayak Mualang dalam Perspektif Kehormatan Katolik, Tesis, STFT Widya Sasana, Malang. 